(2) That it is not altogether easy to regard the limestones as altered sediments.

(3) That whatever their origin they have actually existed in a state "akin to fusion," and as far as their present characters are concerned, are contemporaneous with the charnockite series.

(4) That limestones and the charnockite series have suffered but little from deforming earth-movements since their final solidification.

\title{
NOTIOES OF MEMIIRS, ETC.
}

1. The International Geological Congress.-The next Session of this Congress will be held in Vienna from the 20th to 27th August, 1903. The Austrian geologists have appointed a committee of organization, which has just issued its first circular. The President is Dr. E. Tietze; the general secretary, Professor. C. Diener; and the secretaries, Messrs. F. Teller, G. Geyer, and A. von Böhm. The circular contains a list of the excursions which it is proposed to arrange in connection with the Congress. The following are to take place before the Session:-1. Palæozoic region of Central Bohenia. 2. Hot Springs and eruptive districts in the north of Bohemia; and the surroundings of Brün in Moravia. 3. Galicia, beginning with the coal district of Ostrau and the neighbourhood of Krakau and Wieliczka, then dividing into two sections, one of which visits the petroleum beds, and the other the peaks of the Carpathians and the Tatra Mountain. 4. Salzkammergut. 5. Styria. The following are to be after the Session:-6. Dolomites of the Tyrol. 7. Basin of the Adige in Tyrol. 8. Western region of the Hohe Tauern (Zillerthal Alps). 9. Central region of Hohe Tauern (Venetian Alps). 10. Predazzo. 11. The Carniolan and Julian Alps. 12. Glacial region of the Austrian Alps. 13. Bosnia and Dalmatia. There is also an invitation from the Geological Society of Hungary, which includes a visit to Buda-Pesth and the lower course of the Danube (Cataracts and Iron Gate).

2. Illustrations of Volcanic Phenomena.-There has been arranged at the British Museum a temporary exhibition to illustrate the recent volcanic eruptions in the West Indies, and their phenomena. Within about a fortnight of the eruptions in St. Vincent and Martinique, the Exhibition was installed in that gallery of the Geological Department in which other collections elucidating the dynamic side of geology are already displayed. Now, however, it is placed in one of the bays of the central hall, where it has attracted a large number of visitors. A general guide-label informs the visitor that the Exhibition is arranged in several sections which should be examined in regular order, as follows :-

A series of maps and diagrams, some specially prepared, shows the geography of the Lesser Antilles and the relations of their volcanoes to the general structure of the globe, particularly to the disturbed region of Central America. On these maps, pins have 
been inserted drawing attention to places specially affected during the last few months. Adjoining this are pictures and photographs of the scenery, buildings, vegetation, and human inhabitants of the ruined islands. A noteworthy contribution to this section is the excellent series of sketches lent by the Rev. W. C. Bourchier, R.N. The recent elevation of the Antillean Ridge from great depths is illustrated by specimens of fossil animals and their recent congeners, specially selected for that purpose. Next follow specimens illustrating the volcanic geology of the Lesser Antilles, the dust from this and previous eruptions being, of course, exhibited and explained. We understand that arrangements have been made to acquire further specimens of volcanic ejectamenta from Martinique and St. Vincent. The next section illustrates the fauna and flora of the Lesser Antilles, attention being specially directed to such species as are exceedingly rare (possibly owing to the effects of previous catastrophes) and whose extermination is feared, also to species characteristic of the islands and, as such, mentioned in the accounts of travellers. The portion of the Exhibition having special reference to the Lesser Antilles is concluded by a series of extracts from local newspapers and other notes having reference to present and previous eruptions in that region. The remainder of the Exhibition deals with volcanic phenomena generally : first, by means of a large series of plates and photographs ranging from the sixteenth century to the present year, and representing many of the best known volcanoes of the globe, as well as some of the extinct or possibly dormant volcanoes in various parts of the world; secondly, by a typical series of volcanic products, carefully labelled for the benefit of the public. Dr. Bather and Mr. Prior are responsible for this exhibition.

3. Natural Science Records.-The Geological Record, the Annuaire Géologique, the Annals of British Geology, not to mention less ambitious attempts, having had their day and ceased to be, and the Record of Geological Literature added to the Geological Society's Library having entered on a period of æstivation, it may be of service to indicate yet another bibliography, the "Revue Bibliographique des Sciences naturelles pures et appliquées . . . publiée par J. Chavanon et G. Saint-Yves. . . . Paris, 45, Avenue Ledru. Rollin."

The Revue is announced to appear in monthly parts of five or six octavo sheets, at a subscription price of 30 francs for addresses in the Postal Union.

The programme is far too large to be filled with any success in an annual volume of such restricted size; but by devoting special attention to Agronomic Science the promoters will fill a gap. We cannot say the same for the second feature on which they pride themselves, namely, the indexing all names of new genera and species, or species from new localities, since this is already performed by the Zoological Record and by the Concilium Bibliographicum, Zurich, which two bibliographies supplement each other's inevitable deficiencies. Under each of the main headings-Geology, Mineralogy and Mining, Zoology, Anatomy, and so forth-is given 
an annotated list of the contents of certain parts of a number of periodicals, taken by countries. Each number is completed by an index to the subject-matter and a list of the periodicals noticed in that part. This latter is a useful feature.

4. Dr. F. A. Bather, M.A.-On April 23 the Principal Trustees of the British Museum appointed Dr. F. A. Bather to fill the AssistantKeepership of the Department of Geology, rendered vacant by the promotion of Dr. A. Smith Woodward to the Keepership on the 18 th December previous.

5. Earthqdakes in Greece.-It may not be generally known that there is published a list of earthquakes observed in Greece for the year. 'The list appears in Annales de l'Observatoire Nationale d'Athènes, edited by Professor Démétrius Egrinitis. Volume iii, 1901 (4to, Athènes), contains the earthquakes recorded for the year 1899, in chronological orders. In each case the time is given, its strength noted, direction, length, and the name of the recorder. The utility of this valuable record would be much enbanced if Professor Eginitis would give an alphabetical index to the localities in future lists.

6. Emendations of Ammonite Nomenclature,-Under the above title, Mr. S. S. Buckman has issued an $8 \mathrm{pp}$. pamphlet of revision of the nomenclature in his monograph on the Inferior Oolite Ammonites published by the Palæontographical Society. The pamphlet, at first issued privately in June, has now (July) been published, and is on sale at Norman, Sawyer, \& Co., Cheltenham, price one shilling. It contains numerous new generic and trivial names.

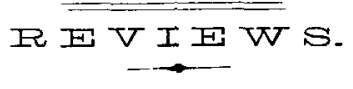

Aids in Practical Geology. By Professor Grenvilue A. J. Cole, M.R.I.A., F.G.S. 4th edition. 8vo; pp. 431. (London : Charles Griffin \& Co., 1902.)

$\mathrm{W}^{\mathrm{B}}$

were able to speak highly of this "eminently practical" work on geology eleven years ago in our notice of the first edition (GEOL. MAG. for 1891, p. 230). We therefore welcome the fourth edition, for it proves that the labours of the author have been appreciated. Those of our readers who have not yet acquired the book should know that it does not deal with economic geology, but is intended as a companion to ordinary textbooks, and to give instruction to the student in the methods of examining and determining minerals, rocks, and fossils. The work has been revised throughout, and amongst the fresh information mention should be made of that on the isolation of the constituents of rocks. The author observes that "Few changes in nomenclature have been introduced into this edition, and the limits of the names of rocks, and even of fossil genera, have been kept as wide as possible." This is right. Nomenclature is the bane of students and of teachers of natural science, in respect of its 'kaleidoscopic' changes; and Professor Cole has not been able to escape them altogether. 